\title{
Teacher beliefs in a CLIL education project
}

\author{
Carmen Pena Díaz \\ María Dolores Porto Requejo \\ Departamento de Filología Moderna \\ Universidad de Alcalá
}

Received: 21 May 2007 / Accepted: 17 November 2007

ISSN: $1697-7467$

\begin{abstract}
One of the most important and interesting questions which researchers studying teaching behaviour have sought to find out is why teachers teach the way they do. The answer to this question ineludibly takes us to the study of teacher beliefs. It is fundamental to conceptualise what teachers believe to be able to understand the way they teach. This paper is part of a research project at the university of Alcalá (Spain) which seeks to study the needs of teachers involved in a bilingual teaching project being carried out in a number of primary schools in Madrid since 2003, whose main object is to integrate the teaching of a foreign language in content subjects (CLIL). The analysis of questionnaires given to teachers working in the project, together with the background research carried out will undoubtedly help us improve our knowledge about teacher beliefs. It is important to mention that most of the teachers working in the aforementioned project have never experienced bilingual teaching or rather CLIL (content language integrated learning). The analysis of their answers to these questionnaires together with some background research will evidence some fears and anxieties about this new way of teaching and the difficulties to abandon certain old conceptions and accept some innovative ones. Key words: Teacher beliefs, CLIL, bilingual education.
\end{abstract}

RESUMEN: Sin duda una de las preguntas más significativas e interesantes para los que trabajan en el campo de la didáctica es porqué enseñan los profesores de una determinada manera. La respuesta a esta pregunta nos lleva ineludiblemente al estudio de la conceptualización de creencias didácticas por parte del profesorado. A su vez, el estudio sobre la conceptualización es fundamental para poder entender cómo enseñan los docentes. Este trabajo forma parte de un proyecto de investigación de la Universidad de Alcalá que pretende estudiar las necesidades del profesorado involucrado en un proyecto bilingüe que se está llevando a cabo en un gran número de colegios públicos de primaria en la Comunidad de Madrid desde 2003 y cuyo objetivo es integrar la enseñanza de una segunda lengua en las asignaturas curriculares (CLIL). El análisis de cuestionarios realizados por profesorado que trabaja en este proyecto así como el estudio de trabajos anteriores sobre el tema nos ayudará sin duda a mejorar nuestros conocimientos sobre las creencias de estos docentes. Es importante el hecho de que estos profesores jamás hayan impartido clase en enseñanza bilingüe. A través de los cuestionarios intentaremos averiguar qué opinan sobre su docencia, además de revelarnos sus miedos y necesidades sobre este nuevo tipo de enseñanza y las dificultades que plantea dejar atrás viejos prejuicios para aceptar nuevos e innovadores métodos.

Palabras clave: Conceptualización de la enseñanza, CLIL, educación bilingüe. 


\section{INTRODUCTION}

Most of a teacher's attitudes and expectations about their teaching come from their own experience as a student which, in turn is passed on to her/his own students. It is therefore very important to study teaching behaviour and why teachers teach the way they do. The answer to this question ineludibly takes us to the study of teacher beliefs. It is fundamental to conceptualise what teachers believe to be able to understand the way they teach.

Since 2003, a bilingual teaching project is being carried out in a number of primary schools in Madrid. The main object of this project is to integrate the teaching of a foreign language in content subjects (CLIL). This paper is part of a research project at the University of Alcalá (Spain) which seeks to study the needs of the teachers involved in this project.

The analysis of questionnaires given to teachers working in the project, together with the background research carried out will undoubtedly help us improve our knowledge about teacher beliefs. It is important to mention that most of the teachers working in the aforementioned project have never experienced bilingual teaching or rather CLIL (content language integrated learning). By means of a series of questionnaires we will try to discover what those teachers think about their teaching: The analysis of their answers to these questionnaires together with some background research will evidence some fears and anxieties about this new way of teaching and the difficulties to abandon certain old conceptions and accept some innovative ones.

Everybody knows what teaching is about. Teachers themselves have some conceptions about what the process of teaching involves and how it must be carried out, and many of their beliefs about this actually come from their own schooldays. The problem with beliefs is that "they travel in disguise and often under alias - attitudes, values, judgements..." (Pajares, 1992: 309). So they are very difficult to identify, not to mention changing them. Nevertheless, it is of great importance to identify those beliefs, as they are at the very basis of the individual teaching methodology: knowing about teachers' beliefs can help to identify sources of frustration when they are based on outdated or erroneous information (Yero 2002). Teacher beliefs influence teaching behaviour and even perceptions on one's own teaching.

\section{BACKGROUND}

Many researchers (Wittrock, 1990; Clark and Peterson, 1986; Clark and Yinger, 1979) have assumed that teachers' approaches to teaching have been influenced by the way that they were taught and have demonstrated that teachers have implicit theories of teaching and learning which influence their approaches to teaching. The study of teachers' beliefs would give a clearer insight of their behaviour. As Pajares (1992: 307) points out "this view is based on the assumption that beliefs are the best indicators of the decisions individuals make throughout their lives (Bandura, 1986; Dewey, 1933; Nisbett \& Ross, 1980; Rockeach, 1968)". It is obvious that an individual's perceptions affect her behaviour and understanding these beliefs is essential to improve their teaching practices. As opposed to other careers in which beginners start off not knowing what their jobs are like (when a lawyer enters the courtroom or a doctor the operating theatre for the first time), beliefs about teaching are already established 
as a child, they generally view teaching as a process of transmitting knowledge and dispensing information (Brookhart \& Fremman, 1992). It is very difficult to change these ideas one adopts so early and thus the complex task of changing is quite difficult. These ideas always transmit cultural concepts which tend to come from one's world.

It is obvious that teachers play a fundamental role in the cognitive development of their students. When it comes to bilingual teachers, their personal baggage, knowledge and concept of bilingualism is of vital importance. Beliefs and conceptualisations are formulated from experiences we have had within a socio-cultural context. For example, our beliefs about the world are given to us through our familiar and educational experiences. In essence, the social structure becomes the mechanism for modelling expectations and standards of the norms of a given community or society.

An extremely important and difficult issue we must deal with when studying this topic is defining "beliefs". As Pajares (1992: 307) claims "beliefs should not be confused with knowledge". Pajares (1992: 313) explains that beliefs have been studied in different fields and therefore no specific definition has been adopted, he suggests that belief is based on evaluation and judgement and knowledge on objective fact. Scholars such as Schunk (1991) suggest that although quantitative methods for assessing beliefs have typically been used, qualitative methods are needed, such as case studies or oral histories to gain additional insights. As Pajares indicates (1992: 327), we will not go very far unless other items such as teacher practices, knowledge and student outcomes are also taken into account.

According to Kyriacou (1986), the way we think about effective teaching is strongly linked to teachers' professional development, examination of which may provide insights for teacher education programmes. Effective teaching is essentially concerned with the best way of achieving the desired student learning by some educational activity. Over the years, thinking about teacher development has been approached in a number of different ways. Kowalchuk (1999) has worked out three useful paradigms addressing the professional development of teachers. They are the technical-developmental perspective, the subject matter orientation, and ecological interpretation of learning to teach, representing a three phases development of professional growth. The teacher development model implies that we can cluster the different characteristics of teachers into a few developmental aspects of a teacher: social development, subject knowledge development, pedagogical development and cognitive development ( $\mathrm{Li}$, 2001). The stages of social development, subject knowledge development, pedagogical development and cognitive development of a teacher will go through the proficiency levels ranging from novice, then competent, to expert ( $\mathrm{Li}, 2001)$. The ability to reflect or selfregulatory capability tends to be the key for teachers' advancement in the continuum (See also Ur, 1990; Marcelo, 1989; Head and Taylor, 1997).

Another issue to take into account other than teachers' experiences and professional development is their inherent cultural baggage. Few studies have examined teacher perceptions for culturally and linguistically diverse populations. Inherent in this lack of studies is an assumption that bilingual education teachers' beliefs are similar to non-bilingual education teachers. In contrast to this assumption, Alexander and Dochy (1995) verified cross-cultural and educational background differences among respondents' conceptions of knowledge and beliefs. Thus, we must not assume that simply because teachers and students share common linguistic and/or cultural experiences, bilingual teachers' intuitive beliefs will assist them in recognizing the needs of language minority children. On the contrary, these teachers' implicit 
theories may create a classroom setting in which hegemonic discourse is evident (see Delgado-Gaitán, 1989).

Bustos Flores (2001) in her broad study on bilingual education teachers' beliefs found out that while personal experiences may initially influence bilingual education teachers' beliefs, these beliefs are reaffirmed, modified, or changed with increased knowledge via teacher preparation or professional experiences.

Some researchers (Felix-Holt \& González, 1999; Lemberger, 1996; Jiménez, Gersten, \& Rivera, 1996; Martínez \& Moore-O’Brien, 1996, Flores, 1999, 2000) have agreed with Vygotsky (1978), who noted that language and culture are symbiotic tools used in the mediation of knowledge. This «interaction of knowledge acquisition» dimension is defined as the teacher's beliefs regarding the interactive processes of language, culture, and thought. Teachers who believe that there is interplay among language, culture, and thought will employ these as symbiotic tools in the creation of knowledge. Shotter (1993) argued that this is a two-way process with individuals' backgrounds giving structure to their way of talking and with ways of talking lending form to their world. Through daily dialogue, joint activity, and negotiation, social cognition is distributed and situated within the context (Lightbrown \& Spada, 1999; Shotter, 1993, 1997). These teachers also recognize their role as guides through the zone of proximal development.

It is obvious that, as educators, we cannot separate ourselves from our social condition and, as posited by Good (1987), teachers' beliefs are ultimately tied to student performance. Furthermore, a teacher's beliefs and ability are reflected in the teacher's performance expectations and in the nature of curriculum assignments, pace, interaction, and general teaching style

\section{FieLdWORK}

\subsection{Participants}

In the year 2005, the government of the Comunidad de Madrid launched an educational project through which bilingual education programmes were to be implemented in 26 primary schools distributed all over the Comunidad de Madrid. The project has continued and now includes approximately 150 primary schools operating a bilingual education or CLIL model.

Since the beginning of this project a group of scholars from the Department of Modern Philology at the University of Alcalá have been studying the development of the teachers involved. Our aim was not to evaluate how well they teach, not to judge their professionalism, but rather to look at how they are able to face the challenge implied in working in a bilingual education programme, how they adapt their personal subjective theories to their new teaching mode, how they cope with the new demands, and what they would need in order to be able to carry out the required change in methodology in an effective way.

\subsection{The bilingual project}

Learning foreign languages has become a priority in teaching in most European countries. One of the ways of reaching this objective and making sure that the foreign language becomes for students an authentic means of communication is by teaching various curricular subjects 
in the foreign language. In this context, the Madrid local government, as other regions in Spain, has set up various programmes for this type of bilingual education, amongst which is one initiated in the Spring of the year 2004 (Act 796/2004 dated $5^{\text {th }}$ March by the Education Council of Madrid) and which is our research group's main concern. In response to the European demands in relation to foreign language acquisition, the main objective of this programme is to create high quality centres of education so as to make students achieve a good command of both the foreign language and the mother tongue and thus bilingual education programmes were implemented as from the following academic year in 26 primary schools distributed all over the region. Via these means, bilingual education, which up to that moment had been a privilege only accessible to the financially strongest, was to be made accessible to students from all social and economic backgrounds. At the moment the number of schools has risen to more than 150 primary schools operating a bilingual education model.

Concerning the way in which this project is being carried out, the Madrid local government is in charge of providing schools with the necessary materials or elements, not only for teachers to do their work, but also to make schools become real or authentic bilingual environments. However, sometimes this material or economical aid has not been translated into a practical help, and thus, these pioneer teachers have had and still have to face many difficulties in relation, mainly, to the use and elaboration of proper materials. At first, there were not enough useful textbooks, but publishers have gone out of their way to create the needed materials for this type of teaching and there are now many interesting and excellent working materials available.

Every bilingual school has the autonomy to choose which subjects they will impart in English. As in the case of the British Council, the only two subjects that can only be taught in Spanish are Spanish Language and Mathematics. The time estimated for all the subjects is approximately 25 hours a week and one third of this time will be taught in English.

As clearly explained in Pena, C. et al. (2007): the results that schools and educational authorities expect to see in the students are based mainly on linguistic issues. Children are supposed to have achieved a good enough command of the foreign language as to enable them to keep fluent conversations. At the same time, writing and reading skills in both the mother tongue and English will be introduced and developed. And finally, another of the objectives is that at least the subjects of Natural Science, History and Geography will be taught in English during the 6 years of Primary education. During the last semester of the Sixth grade, students will be evaluated by external examiners. This will allow them to gain those certifications that can be homologated and recognized internationally.

The teachers must fulfil some requirements in order to join the programme. In first place, they must be English teachers, or must be qualified to teach English as a foreign language. Those teachers working with a CLIL programme at school will designate among them a supervisor or coordinator that must forcibly be a qualified teacher specialized in English. This person must be a civil servant with the definite destination at the school in question so as to guarantee the stability and continuity of the programme. The figure of the coordinator will be in charge of enhancing and promoting the project among colleagues and families in relation to those activities that could represent a benefit for the project, such as intercultural exchanges, or cultural trips, that could help students not only achieve the foreign language but also the foreign culture. Besides, every school will receive the support of at least two native speakers of English that will cooperate with the teachers. These Teaching Assistants are mainly students 
with little or no experience in teaching in public schools, and they represent a fundamental opportunity that students have to be exposed to different accents, and to acquire more and faster fluency in developing speaking and listening skills.

\subsection{Questionnaires}

To find out how this group of teachers understands their everyday work we gave them the questionnaires below which they answered in their own time. The first questionnaire gave us feedback of a general character, our aim was to try to find out what they thought of bilingual education, what their needs were and how they felt about their teaching. In the second one our aim was to reach more specific conclusions as to their conceptualisation of bilingual teaching.

\subsubsection{Questionnaire 1}

1. ¿Consideras que la educación bilingüe es positiva para los alumnos? ¿Por qué?

2. ¿En qué consiste, para ti, la educación bilingüe?

3. Indica en qué porcentaje del tiempo el idioma de clase es el inglés (rodea la opción que corresponda)

4. ¿Qué porcentaje del tiempo de clase dedicas a las siguientes actividades?

5. ¿Cómo describirías tu nivel de inglés?

6. ¿Crees que tu docencia mejoraría si tuvieses un nivel más alto de inglés?

7. ¿Tienes conocimientos teóricos sobre cómo impartir docencia bilingüe? Si es así, ¿cuáles?

8. ¿Crees que tu docencia mejoraría si tuvieses más conocimientos pedagógicos con relación a la enseñanza bilingüe?

9. ¿Qué tipo de formación crees que podría beneficiarte para impartir clases bilingües?

10. ¿Podrías indicarnos lo siguiente haciendo referencia a las clases bilingües?:

- Alguna complicación surgida a raíz de la implantación del proyecto bilingüe en tu centro/aula.

- Algo positivo que te haya ocurrido en tu labor docente

- Algo que hayas aprendido

- Algo que crees que sería importante aprender para convertirte en mejor docente

\subsubsection{Questionnaire 2}

1.- ¿Qué relación verías entre estos conceptos y la enseñanza bilingüe ?
a) Cultura
b) Desarrollo de la lengua materna
c) Desarrollo cognitivo de los alumnos
d) Desarrollo personal de los alumnos (afectivo, de conductas y hábitos)

2.- Indica hasta qué punto estás de acuerdo con las siguientes afirmaciones y por qué:

a) La educación bilingüe es altamente positiva, pero da lugar a equívocos llamarla "bilingüe". Nuestros alumnos no serán bilingües porque la situación comunicativa en sus vidas no lo es. 
b) La ventaja principal de la enseñanza bilingüe es que ofrece la posibilidad de que los alumnos aprendan mejor una lengua extranjera.

c) El proyecto de la CAM no es un proyecto de enseñanza bilingüe propiamente dicho, sino que se trata de un proyecto educativo en el que se han aumentado las horas de enseñanza de / en lengua inglesa.

d) Para impartir los contenidos en una lengua extranjera hay que adoptar una metodología diferente.

e) Para impartir docencia en los niveles de primaria basta con tener un nivel intermedio de lengua.

f) El hecho de que la lengua extranjera se utilice para impartir conocimientos hace que la enseñanza de la lengua extranjera sea más "comunicativa".

g) Para los alumnos resulta natural utilizar otra lengua para aprender, por lo cual en principio no deberían tener más problema que el de conocer los términos necesarios en inglés.

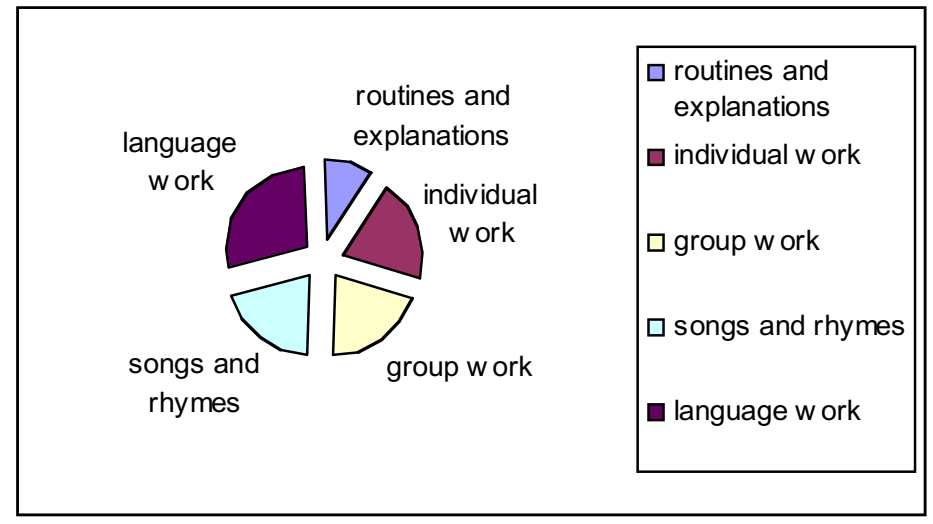

\section{Results TO QUESTIONNAIRES}

\subsection{Results to Questionnaire 1}

Once they answered the questionnaire, we analysed them and the results were the following:

1)They consider this project extremely positive. Only $15 \%$ of the total number of teachers mention a negative aspect, such as it not meeting the needs of students with learning disabilities. They do mention the fact that the term "bilingual" is not properly used for this type of education (CLILL). They view the project so positively mainly because of the amount of hours dedicated to the study of English (as opposed to the normal curriculum, in which they would have many less) and the young age of the students, which permits them to learn more effectively. Only $15 \%$ of the teachers state the fact that students are also learning about and understanding a different culture, as well as acquiring specific attitude contents, such as the capacity to be more tolerant, open and to be able to adapt to different situations. 
The emphasis which they make on the language learning rather than these other issues shows their perception of the need to acquire a higher fluency level for their future and their slight feeling of inferiority with regards to the "minimum required level" in the rest of Europe.

2)The term "bilingual" is correctly considered slightly exaggerated. For most teachers, the objective of this programme is to maximize the acquisition of a second language by spending more time dedicated to it and therefore acquiring a higher level at a younger age. Not many (15\%) state that it is a more "natural" way of acquiring a language. A few teachers $(8 \%)$ mention the high amount of work teachers have to dedicate to the project.

3) Only 50\% uses English all or most of the time. 30\% admit they use the target language less than half of the period time.

4) The following chart summarises the findings:

5)Teachers' levels range from high to high-intermediate. However...

6)Only $16 \%$ think their level is good enough to teach these classes. They believe their teaching would improve if their English was better. This would show either a low self-esteem or that they are not aware of other issues which could help them meet their expectations.

7) $40 \%$ of the participants do not have specific knowledge of bilingual methodology and the rest have attended short introductory courses on the subject. Most of them fall back on their colleagues' experience.

8)Most of these teachers belief that they need more theoretical knowledge, but $30 \%$ think you learn more by everyday experience, or their colleagues', they do not think what they need can be taught. Some think Second Language Teaching methodology can be extrapolated to Bilingual teaching.

9) With regard to the type of training they need to teach bilingual classes, a third of them think they need to improve their English, 30\% would like to see what other colleagues do, either at their own school or in different bilingual or English/International centres. The rest think it would help having specific tasks that they could use for concrete activities.

10)

1)There were a few complications which occurred during the organization of the project due to the involvement of all the teachers. They had problems getting materials and resources. They would prefer smaller groups. These problems, however, do not seem specific of bilingual education. Only one teacher mentions a specific problem for this type of teaching: the loss of affection due to the language barrier created.

2)They are unanimously astonished by the way children are adapting and learning, which basically means that the project is working as well as expected. Another important issue they mention is that, as the project is new, all the teachers in their schools (and not only those working on this project) become involved.

3)Two main points: i) the project is working well (i.e. children are learning English naturally) ii) They feel they are constantly learning, not just a second language but new resources for their new needs (e.g. visual resources).

4)Almost $40 \%$ think they need a higher level of English.

\subsection{Results to Questionnaire 2}

1) Teachers find a strong relationship between learning a language and learning about its culture. In the schools involved in this project they find this relationship reinforced by their 
Twin School Project which consists in having a school in the UK with which the teachers and students share experiences, communicate frequently, etc. Half of the teachers believe culture is implicit in language learning, whereas the other 50\% think it should be explicitly taught by means of projects and contents which develop an interest in the children in the other culture.

As for the development of L1 and students' cognitive development, views are contradictory. Almost all (80\%) teachers stated that bilingualism improves cognitive development because students have to develop abilities and strategies to remember a greater amount of vocabulary and because they are required to make more of an effort. However, $70 \%$ seem to be concerned about the influence that this early acquisition of a second language will have on their L1. Only 30\% are convinced that their linguistic abilities will develop positively and that their L1 acquisition process will be reinforced. $30 \%$ stated that they believed that learning a second language from such early stage will interfere negatively with the L1 acquisition process.

The answer to the question of whether children acquire new vocabulary effortlessly is again contradictory. $50 \%$ of the teachers answered negatively to this question, they think it is quite difficult for children to acquire new vocabulary unless they had previous knowledge of the language during Kindergarten and therefore they would need extra effort and support from teachers and parents. Only half of the teachers, thus, believe children acquire vocabulary naturally and effortlessly.

Teachers with students with special needs believe those children should not participate in the project as they have different needs that should be dealt with before handling learning a second language, let alone bilingualism. They said that it is already hard for them to acquire new concepts in their own language.

As for their personal development, only $10 \%$ think bilingualism does not influence them. $90 \%$, on the other hand, believe bilingualism improves their self-esteem, tolerance towards other cultures and languages and to different things. Studying another language is highly motivating, they enjoy it and think it is fun.

2) All teachers admit that this particular project is not exactly bilingual, as there is no further linguistic input at home or outside school. In any case, they believe this experience to be highly positive for L2 acquisition as it increases the number of hours dedicated to English and the transfer of content in English makes learning more natural. They also mention that this makes language learning more communicative and also that the teaching of contents in L2 makes learning more meaningful, communicative and fun.

An added benefit typical of this type of education model aside from learning another language is that the participating schools have more resources, materials, staff, etc. $60 \%$ of the teachers think CLIL methodology is more communicative, visual, active... whereas $40 \%$ admit that this should also be the methodology used in monolingual classes: role plays, games, changing activities frequently, using visual resources...

Another issue which worried most teachers was their own training. They all think teachers working in this project should have an advanced level of English and in general, at present, this is not the case. They say that teachers ought to have the necessary training and they are very happy to have language assistants. 


\section{Conclusions}

Teachers view bilingualism positively but, on the other hand, think that the L2 will interfere in their L1 acquisition. This is probably due to the difficulty they seem to have to get away from traditional teaching models. That is, on the one hand, they are positive that bilingual learning has lots of advantages, but, on the other hand, they would prefer to keep their old traditional models arguing that the L1 vocabulary was better before. In fact, in many schools they have designed strategies to make sure content vocabulary is learned in both L1 and $\mathrm{L} 2$.

All teachers agree that the bilingual project is not exactly "bilingual" but, should be denominated, content teaching in another language (CLIL or Content Language Integrated Learning) where the amount of weekly hours taught in English is increased considerably. They do not, however, consider aspects such as the acquisition of a different culture or factors such as tolerance, broadmindedness, etc. important.

Although they think they have a high or intermediate-high level of English, they do not feel confident and think their teaching would improve if their level was higher and argue that they would need further language training. However, they do not consider they need theoretical training concerning bilingual methodology, although they have hardly had any. On the other hand, they show interest in practical knowledge on their specific subjects. They specially rely on their own and their colleagues' experience and on a continuous self learning, which is the reason why they probably feel so insecure about what they do in class, although they see their students' linguistic evolution and quick adaptation to the new system. For future CLIL teachers, ideally, they should have available some teacher training courses specifically designed for this type of education both at the universities where they studied and at the training courses (CAP). As for the teacher presently working on this program, they complain about the lack of time to carry out many activities inside and outside the class, which will undoubtedly influence the way training courses may be introduced to them, as it will be difficult to enrol for a course held along the academic year. An alternative could be the offer of on-line courses, in which teachers could learn contents with the help of a tutor and/or the design of summer courses, short and focused on specific needs of these teachers. The CAM should provide funds to help these teachers complete their training. These courses would need to take into consideration the need to improve their competence in the English language and, more specifically, to acquire knowledge about structures and vocabulary related to the subjects they teach, classroom language in general. It also essential for teachers to understand the importance of providing a good model of pronunciation at primary level. As far as methodology is concerned, teachers perceive that their needs are different from those of the teachers not working on bilingual projects. For this reason, courses could be complemented with practical sessions in bilingual schools set in Spain or abroad.

A small percentage (around 10\%) is concerned about individual attention which can be reduced due to the language barrier or to students with special needs who, they argue, are not fit to learn new concepts in English. However, these students already have problems in the L1, so it does not seem that learning a second language will increase or decrease that cognitive gap. Students with cognitive problems in their own language are bound to have problems acquiring a second language as well as acquiring other content concepts and, contrary to what 
the teachers believe, might feel more motivated and interested in learning new concepts through their second language in a different and fun way.

All of this indicates that they have a low self esteem not only about their language but also about their teaching. They mention that they would like to see other colleagues at work. They also think that extra materials and resources adapted to their new needs would help them.

Only half of the teachers, therefore, think children acquire vocabulary naturally and spontaneously. This could indicate problems which teachers are facing due to their believing previously that the process would be faster.

A very positive feature we could conclude with is that teachers are very motivated and dedicated to this project, which will consequently help them work to improve it and become a model for schools who have not yet implemented it.

\section{REFERENCES}

Bandura, A. (1986). Social Foundations of thought and acting: A social cognitive theory. Englewood Cliffs, NJ: Prentice Hall.

Brookhart, S.M. \& Fremman, D.J. (1992). Characteristics of entering Teacher Candidates. Review of Educational Research, 62: 37-60.

Bustos Flores, B. (2001). Bilingual Education Teachers' Beliefs and Their Relation to SelfReported Practices. Bilingual Research Journal, 25(3).

Clark, C. M., and P. L. Peterson. (1986). «Teachers' thought processes.» 3rd edition. In Wittrock (1986).

Clark, C.M \& Yinger. (1979). “Teachers thinking”. In Peterson, P. and Walberg, H. J. Research on teaching concepts findings, and implications. Berkeley: Mc Cutchan Publishing Corporation.

Dalton-Puffer, C. (2004). "Content and language integrated learning in Austrian classrooms: applied linguistics". In http://www.univie.ac.at/Anglistik/views/ 02_1\&2/CDP.PDF.

Good Good, T. L. (1987). Teacher expectations. In D. C. Berliner \& B. V. Rosenshine (Eds.), Talks to teachers (pp. 159-200). New York: Random House.

Head, K. and Taylor, P. 1997. Readings in Teacher Development. Oxford: Heinemann.

Marcelo, C. (1989). Introducción a la formación del profesorado: Teoría y métodos. Sevilla: Servicio de Publicaciones de la Universidad de Sevilla

Markee, N. (1994). Curricular Innovation: Issues and Problems. Applied Language Learning, 5(2) $1-30$.

Nisbett, R. \& Ross, L. (1980). Human inference: Strategies and shortcomings of social judgement. Englewood Cliffs, NJ: Prentice Hall.

Pajares, F. (1992). Teachers' Beliefs and Educational Research: Cleaning Up a Messy Construct. Review of Educational Research, 62(3): 307-332.

Ur, P. (1997). A Course in Language Teaching. Cambridge University Press.

Urrutia, H., Candia, L., Martínez, Ma D. \& Milla, F. 1998. Bilingüismo y rendimiento académico en la Comunidad Autónoma Vasca. Bilbao: Jóvenes por la Paz.

Wittrock, Merlin C. (ed.) (1986). Handbook of research on teaching. 3rd edition. New York: Macmillan Publishing Co. xi, 1037. 0029003105. Location: Howard Payne University, Walker Memorial Library, Brownwood, TX.

Wittrock, M. (1990). La Investigación de la enseñanza. Barcelona: MEC/Paidós. 